Tersedia online di http://ojs.unik-kediri.ac.id/index.php/jimek JIMEK

Pengaruh Current Ratio, Total Asset Turnover, Net Profit Margin Terhadap Perubahan Laba Pada Perusahaan Perdagagan Jasa Dan Investasi Yang Terdaftar Di Bursa Efek Indonesia Periode 2014-2017

\author{
Rika Wani Juwita Hutagalung ${ }^{1}$, Yois Nelsari Malau ${ }^{2}$ \\ Universitas Prima Indonesia \\ email: ${ }^{1}$ rikawanijuwita@gmail.com, ${ }^{2}$ yoisnelsarimalau@gmail.com
}

\section{Artikel History:}

Artikel masuk : 18-03-2020

Artikel revisi : 27-03-2020

Artikel diterima : 23-06-2020

Keywords:

Current Ratio, Total Asset

Turnover,Net Profit Margin dan

Perubahan Laba
Tujuan penelitian ini adalah untuk menguji dan menganalisis pengaruh current ratio, total asset turnover, net profit margin terhadap perubahan laba pada perusahaan perdagangan jasa dan investasi yang terdaftar di BEI periode 2014-2017. Variabel independen menggunakan current ratio, total asset turnover,net profit margin sedangkan variabel dependennya perubahan laba. Populasi berjumlah 134 perusahaan dengan mengambil data laporan keuangan pada perusahaan perdagangan jasa dan investasi yang terdaftar di BEI. Sampel penelitian menggunakan purposive sampling diperoleh sebanyak 45 sampel. Penelitian ini menggunakan pendekatan kuantitaif, jenis penelitian deskriptif, sifat penelitian hubungan kausal. Teknik pengumpulan data dengan teknik dokumentasi. Uji analisis statistik yang digunakan yaitu uji asumi klasik, model penelitian analisis linier berganda, dan koefisien determinasi menggunakan uji simultan dan uji parsial pada tabel nilai signifikan sebesar 0,05. Hasil penelitian secara parsial current ratio, total asset turnover, net profit margin tidak berpengaruh positif dan tidak signifikan terhadap perubahan laba. Secara simultan current ratio, total asset turnover,net profit margin berpengaruh dan signifikan terhadap perubahan laba Hasil uji Adjusted R Square menunjukkan 1,1\% dari variasi variabel dependen perubahan laba yang dapat dijelaskan oleh current ratio, total asset turnover,net profit margin sedangkan sisanya $98,9 \%$ dijelaskan oleh variabel lain yaitu diluar penelitian ini contohnya ukuran perusahaan, modal dan deviden.

\section{ABSTRACT}

The purpose of this study was to examine and analyze the effect of the current ratio, total asset turnover, net profit margin on changes in profits in the service trading and investment companies listed on the Indonesia Stock Exchange in the 20142017 period. The independent variables used in this study are, current ratio, total asset turnover, net profit margin while the dependent variable changes earnings. The population used in this study amounted to 134 companies by taking the financial statement data that is in the service trading and investment companies listed on the Indonesia Stock Exchange. The sample of this study was taken using purposive sampling obtained as many as 45 samples. This research uses a quantitative approach, descriptive research type, the nature of causal relationship research.Data collection techniques with documentation 
techniques. The statistical analysis test used is the classic asumi test, multiple linear analysis research model, and the coefficient of determination using the simultaneous test and partial test on the table of significant values of 0.05. The results of this study indicate partially the current ratio, total asset turnover, net profit margin does not have a positive and significant effect on changes in earnings, Simultaneously current ratio, total asset turnover, net profit margin influence and significantly affect earnings changes Adjusted $R$ Square test results show $1.1 \%$ of the variation in the dependent variable changes in earnings that can be explained by the current ratio, total asset turnover, net profit margin while the remaining $98.9 \%$.is explained by other variables that are outside this study for example company size, capital and devidens.

\section{PENDAHULUAN}

Perkembangan teknologi dan informasi mendorong pertumbuhan dan persaingan di dunia industri semakin kuat. Perusahaan - perusahaan yang ingin bertahan dan lebih maju perlu mengembangkan strategi baru. Dalam perekonomian seperti ini tidak satu pasar pun yang selamanya aman dari persaingan, baik lokal maupun global. Begitu pula yang terjadi pada perusahaan di sektor industri perdagangan, jasa dan investasi yang terdaftar di Bursa Efek Indonesia (BEI).

Bursa Efek Indonesia mencatat lebih dari 100 (seratus) perusahaan yang termasuk kedalam sektor perdagangan, jasa dan investasi. Sektor perdagangan, jasa dan investasi merupakan gabungan dari beberapa sub sektor yang terdiri dari: sub sektor perdagangan besar barang produksi; sub sektor perdagangan eceran; sub sektor restoran, hotel dan pariwisata; sub sektor periklanan, percetakan dan media; sub sektor kesehatan; sub sektor jasa komputer dan perangkat; dan sub sektor perusahaan investasi.

Perkembangan serta pertumbuhan sub sector perdagangan besar atau eceran sangat berkaitan dengan kinerja impor dan komsumsi masyarakat. Meningkatnya daya beli masyarakat akan mendorong naiknya laju pertumbuhan komsumsi masyarakat dimana permintaan akan barang - barang komsumsi baik dalam maupun luar negeri juga meningkat. Dengan melihat lambatnya pertumbuhan perdangangan di Indonesia menuntut perusahaan agar lebih meningkat kelangsungan hidup perusahaanya dengan analisis dan pemetaan sebagai gambaran perkembangan usahanya dan mampu meningkatkan kinerja keuangan perusahaan kedepanya, sehingga perkembangan perusahaan dagang di Indonesia dapat meningkatkan setiap tahunnya. Penjualan mencerminkan pencapaian perusahaan dimasa lalu, dimana pertumbuhan penjualan digunakan untuk memprediksikan pencapain dimasa depan.

Current ratio menunjukan sejauh mana aktiva lancar menutupi kewajiban-kewajiban lancar. Semakin besar perbandingan aktiva lancer dengan kewajiban lancer semakin tinggi 
kemampuan perusahaan menutupi kewajiban jangka pendek. Current ratio yang rendah biasanya dianggap menunjukkan terjadinya masalah dalam likuiditas, sebaliknya current ratio yang terlalu tinggi juga kurang bagus, karena menunjukkan banyaknya dana menggangur yang pada akhirnya dapat mengurangi kemampuan laba perusahaan. Setiap organisasi yang merupakan organisasi yang berorientasi pada profit motive mempunyai tujuan untuk memperoleh laba setiap kegiatan operasional yang dilaksanakan investasi untuk menghasilkan laba.

Rasio TATO tersebut sangat besar sekali pengaruhnya dalam menghasilkan laba, pengertian yang lebih tentang TATO adalah rasiso yang digunakan untuk mengukur perputaran semua aktiva yang dimiliki perusahaan.Permasalahan yang akan diteliti dalam penelitian ini adalah bagaimana total assets turnover berpengaruh terhadap perubahan laba pada perusahaan perdangangan jasa dan investasi.

Perubahan laba menjadi salah satu informasi prediksi yang sangat penting bagi para pengguna laporan keuangan yang menggambarkan prospek hasil usaha dan keadaan keuangan perusahaan di masa yang akan datang.Dengan laba bersih perusahaan dapat mengukur laba yang dihasilkan dari setiap transaksi penjualan yang terjadi di perusahaan tersebut. Dan dengan laba bersih atas penjualan ini juga mengukur efesiensi, baikproduksi, administrasi, pemasaran, pendanaan, penetuan harga maupun manejemen pajak. Meskipun laba bersih yang diharapkan tinggi, akan tetapi karena adanya kekuatan persaingan industri, kondisi ekonomi, pendanaan utang, dan karakteristik operasi, maka rasio ini biasanya berbeda diantara perusahaan. Perubahan laba dipengaruhi olehbeberapa factor antara lain: Current Ratio,Total Assets Turnover dan Net Profit Margin.

\section{TINJAUAN PUSTAKA}

\section{Pengertian Current Ratio}

Menurut Kasmir (2012:135) Rasio lancar (current ratio) merupakan rasio untuk mengukur kemampuan perusahaan untuk membayar kewajiban jangka pendeknya atau utang yang segera jatuh tempo pada saat ditagih secara keseluruhan. Dengan kata lain, seberapa banyak aktiva lancar yang tersedia untuk menutupi kewajiban jangka pendek yang segera jatuh tempo.

Menurut Kasmir (2015:310) rasio lancar ini menggambarkan seberapa besar jumlah ketersediaan aset lancar yang dimiliki perusahaan dibandingkan dengan total kewajiban lancar, oleh sebab itu, rasio lancar dihitung sebagai hasil bagi antara total aset lancar dengan total kewajiban lancar. $\mathrm{CR}=$ Aktiva lancer/utang lancar 
R W J Hutagalung, Y N Malau / Jimek vol 3 no 1 tahun 2020

\section{Pengertian Total Assets Turnover}

Menurut Sitanggang (2012:28), mengemukakan TATO yaitu rasio yang mengukur bagaimana seluruh

aktiva yang dimiliki perusahaan dioperasionalkan dalam mendukung penjualan perusahaan. Semakin tinggi produktivitas penggunaan seluruh asset perusahaan.

Menurut Kasmir (2015:186), rumus untuk mencari total assets turnover adalah sebagai berikut: $\mathrm{TATO}=$ Penjualan/Total Aktiva

\section{Pengertian Net Profit Margin}

Menurut Hery (2015:235), merupakan rasio yang dingunakan untuk mengukur besarnya presentase laba bersih atas penjualan bersih.

Menurut Kasmir (2015:196), adapun rumus untuk menghitung Net Profit Margin adalah: NPM=Laba bersih/ Penjualan bersih

\section{Pengertian Perubahan Laba}

Menurut Hamidu (2013:713), Pertumbuhan Laba yang dimaksud dalam penelitian ini dihitung dari selisih jumlah laba tahun yang bersangkutan dengan jumlah laba tahun sebelumnya dibagi dengan jumlah laba tahun sebelumnya

Menurut Harahap (2015:310), Perubahan Laba dapat dikategorikan sebagai rasio pertumbuhan yaitu rasio kenaikan laba bersih yang dihitung dengan cara mengurangkan laba bersih tahun ini (laba t) dengan laba bersih tahun lalu (laba t-1) yang kemudian dibagi dengan laba bersih tahun lalu (labat-1)

Atau rumus perhitungan adalah: KLB= Laba bersih tahun ini-Laba bersih tahun lalu/laba bersih tahun lalu

\section{Teori Pengaruh Current Ratio}

Menuru Sawir (2015:8), Current ratio rendah biasanya dianggap menunjukkan terjadinya masalah dalam kualitas ,sebaliknya suatu perusahaan yang current ratio-nya terlalu tinggi juga kurang bagus, karena menunjukkan banyaknya dana menganggur yang pada akhirnya dapat mengurangi kemampuan labaan perusahaaan.

\section{Teori Pengaruh Total Assets Turn Over}

Menurut Hery (2014:187), menyatakan bahwa Perputaran total asset yang rendah berarti perusahaan memiliki kelebihan total asset dimana total aset yang ada belum dimanfaatkan secara maksimal untuk menciptakan penjualan

\section{Teori Pengaruh Net Profit Margin}


Menurut Hery (2017: 317), Semakin tinggi marjin laba bersih berarti semakin tinggi pula laba bersih yang dihasilkan dari penjualan bersih. Hal ini dapat disebabkan karena tingginya laba sebelum pajak penghasilan. Sebaliknya, semakin rendah marjin laba bersih berarti semakin rendah pula laba bersih yang dihasilkan dari penjualan bersih. Hal ini dapat disebabkan karena rendahnya laba sebelum pajak penghasilan.

\section{Kerangka Konseptual}

Dalam penelitian ini, variable independen yang digunakan adalah Current ratio (X1), Total Assets Turnover (X2), dan Net Profit Margin( X3), sedangkan variabel dependen yaitu Perubahan Laba (Y). Dimana penelitian ini bertujuan untuk mengetahuai dang menganalisis pengaruh variabel independen tersebut dengan terhadap (Y) Perubahan laba pada perusahaan perdangangan jasa dan investasi yang terdaftar di bursa efek Indonesia periode 2014-2017

\section{Gambar 1 Hipotesis Penelitian}

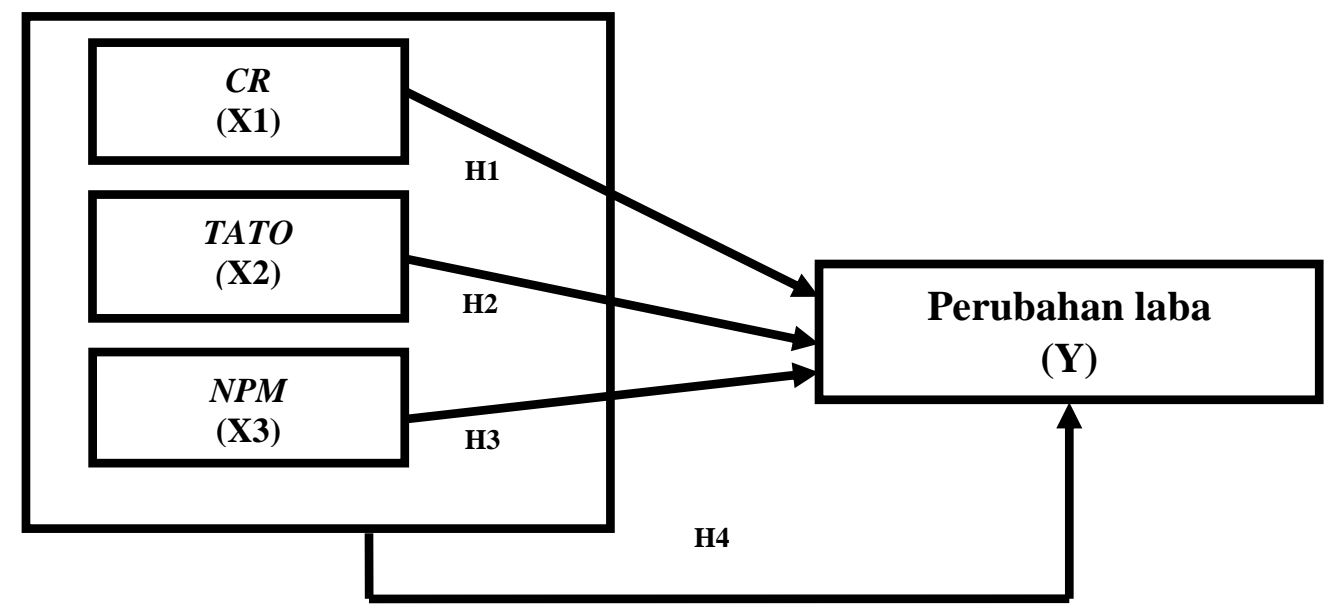

Hipotesis dapat diartikan sebagai suatu jawaban yang bersifat sementara terhadap masalah yang diajukan, dan jawaban itu masih akan diuji secara empiris kebenarannya. Hipotesis dalam penelitian ini adalah :

H1: Current Ratio berpengaruh terhadap perubahan laba dalam pelaporan keuangan pada perusahaan Perdangangan Jasa dan Investasi di BEI periode 2014-2017

H2 : Total Assets Turnover berpengaruh terhadap perubahan laba dalam pelaporan keuangan pada perusahaan Perdangangan Jasa Investasi di BEI periode 2014-2017

H3 : Net Profit Margin berpengaruh terhadap perubahan laba dalam pelaporan keuangan pada perusahaan Perdangangan Jasa dan Investasi di BEI periode 2014-2017

H4 : Current Ratio, Total Assets Turnover dan Net Profit Margin terhadap perubahan laba dalam pelaporan keuangan pada perusahaan Perdangangan Jasa dan Investasi di Bursa Efek Indonesia periode 2014-2017. 


\section{METODE PENELITIAN}

Penelitian ini menggunakan pendekatan kuantitatif, jenis penelitian yang dingunakan adalah deskriptif kuantitatif dan sifat penelitian yang dingunakan adalah explanatory.

\section{Uji Asumsi Klasik}

Syarat dalam menggunakan model regresi berganda dengan metode Ordinary least square (OLS) adalah terpenuhinya semua asumsi klasik agar hasil pengujian tidak bersifat bias dan efisiensi ( Best Linear Unbiased Estimator/BLUE).Uji asumsi klasik yang dilakukan dalam penelitian ini antara lain uji normarlitas, uji autokorelasi, uji multikonelitas dan uji heteroskedastistas.

\section{Model Penelitian}

Metode analisis data ini menggunakan analisis regresi berganda. Model regresi berganda yang dingunakan adalah sebagai berikut :

$\mathbf{Y}=\mathbf{a}+\mathbf{b}_{1} \mathbf{X}_{1}+\mathbf{b}_{2} \mathbf{X}_{2}+\mathbf{b}_{3} \mathbf{X}_{3}+\mathbf{b}_{4} \mathbf{X}_{4}+e$

Keterangan :

$\begin{array}{ll}\mathrm{Y} & : \text { Return on Asset } \\ \mathrm{a} & : \text { Konstanta } \\ \mathrm{b}_{1} \mathrm{~b}_{2} \mathrm{~b}_{3} & : \text { Koefisien Regresi } \\ \mathrm{X}_{1} & : \text { Current Ratio } \\ \mathrm{X}_{2} & : \text { Total Assets Tunover } \\ \mathrm{X}_{3} & : \text { Net Profit Margin } \\ \mathrm{e} & : \text { standar } \text { error (tingkat kesalahan) } 5 \%\end{array}$

\section{Koefisien Determinasi Hipotesis $\left(\mathbf{R}^{2}\right)$}

Menurut Ghozali (2016:95) Koefisien determinasi $\left(\mathrm{R}^{2}\right)$ pada intinya mengukur seberapa jauh kemampuan model dalam menerangkan variasi variabel dependen. Nilai koefisisen determinasi adalah nol dan satu. Nilai $\mathrm{R}^{2}$ yang kecil berarti kemampuan variabelvariabel independen dalam menjelaskan variasi variabel-variabel dependen amat terbatas. Nilai yang mendekati satu berarti variabel-variabel independen memberikan hampir semua informasi yang dibutuhkan untuk memprediksi variasi variabel dependen. Setiap tambahan satu variabel indenpen maka $\mathrm{R}^{2}$ pasti meningkat tidak peduli apakah variabel tersebut berpengaruh secara signifikan terhadap variabel dependen. Oleh karena itu, banyak peneliti menganjurkan untuk menggunakan nilai adjusted $\mathrm{R}^{2}$ pada saat evaluasi model regresi terbaik. Tidak seperti $\mathrm{R}^{2}$, nilai adjusted $\mathrm{R}^{2}$ dapat naik atau turun apabila satu variabel independen ditambahkan kedalam model. 
Kelemahan mendasar koefisien determinasi adalah bias terhadap jumlah variabel independen yang dimasukkan kedalam model. Setiap tambahan satu variabel independen, maka $\mathrm{R}^{2}$ pasti meningkat tidak perduli apakah variabel tersebut berpengaruh secara signifikan terhadap variabel dependen. Oleh karena itu banyak peneliti menganjurkan untuk menggunakan nilai adjusted $\mathrm{R}^{2}$ pada saat mengevaluasi mana model regresi terbaik. Tidak seperti $\mathrm{R}^{2}$, nilai adjusted $\mathrm{R}^{2}$ dapat naik atau turun apabila satu variabel independen ditambahkan kepada modal.

\section{Pengujian Hipotesis Secara Parsial}

Menurut Ghozali (2016 : 99), uji ini digunakan untuk menunjukkan seberapa jauh pengaruh satu variabel penjelas atau independen secara individual dalam menerangkan variasi variabel dependen.

\section{Pengujian Hipotesis Secara Simultan}

Menurut Ghozali (2016 : 98), uji statistik F pada dasarnya menunjukkan apakah semua variabel independen atau bebas yang dimasukkan dalam model mempunyai pengaruh secara bersama - sama terhadap variabel dependen atau terikat.

\section{Hasil Dan Pembahasan}

Hasil Uji Asumsi Klasik

\section{Uji Normalitas histogram}

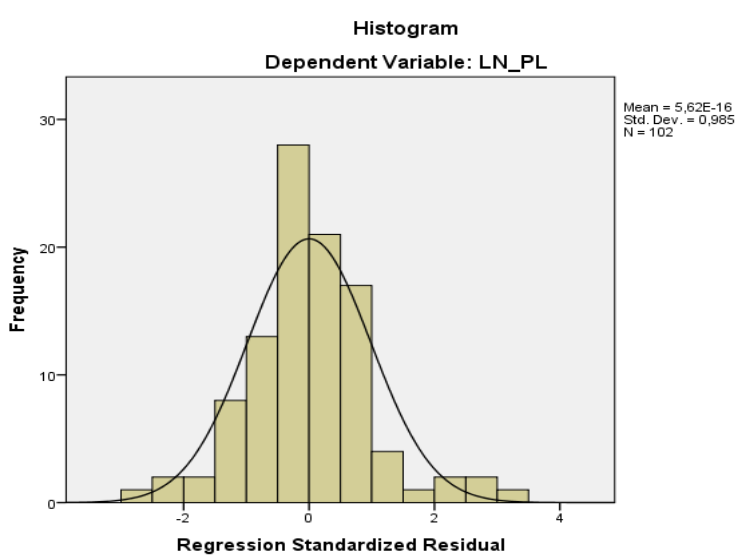

Sumber : Hasil Pengolahan Data

Dapat dilihat bahwa grafik menunjukan garis kurva cenderung simetris (U) dan tidak melenceng ke kiri maupun ke kanan. Hal ini menunjukkan bahwa data variabel bebas yaitu Current Ratio,Total Assetsb Turnover, Net Profit Margin serta variabel terikat yaitu Perubahan Laba dapat dikatakan data berdistribusi normal.

\section{Uji Multikolinearitas}




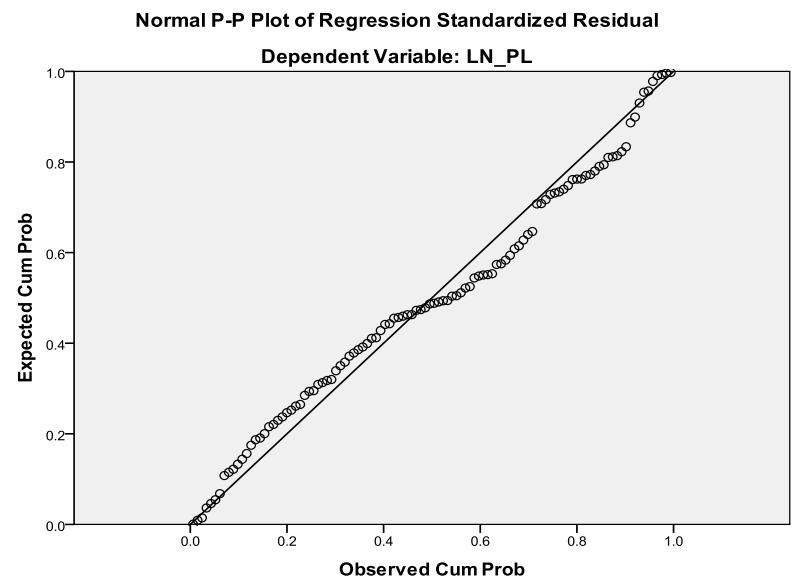

Sumber : Hasil Pengolahan Data

Berdasarkan hasil analisis P-Plot menunjukkan pada model regresi terlihat titik-titik menyebar dan mendekati garis diagonal.Artinya dapat disimpulkan bahwa hasil data uji normalitasanalisis grafik telah berdistribusi normal.Selain analisis grafik, perlu dilakukan analisis statistik dengan melakukan uji kolmogorov smirnov untuk memastikan apakah data benar-benar telah berdistribusi normal.

\section{Uji Normalitas Kolmogorov Smirnov}

\begin{tabular}{|ll|r|}
\hline & & $\begin{array}{c}\text { Unstandardized } \\
\text { Residual }\end{array}$ \\
\hline $\mathrm{N}$ & Mean & 108 \\
Normal & Std. \\
Parameters & 0 \\
& Deviation & 1.564815 \\
Most & Absolute & 0.076 \\
Extreme & Positive & 0.076 \\
Differences & Negative & -0.055 \\
& Kolmogorov-Smirnov Z & 0.785 \\
Asymp. Sig. (2-tailed) & 0.569 \\
\hline
\end{tabular}

\section{Sumber : Hasil Pengolahan Data}

Berdasarkan tabel dapat dilihat Kolmogorov Smirnov menunjukan nilai signifikan 0,569 lebih besar dari 0,05 dengan demikian hasil uji normalitas Kolmogorov Smirnov dapat diambil kesimpulan data berdistribusi normal. 


\begin{tabular}{|rr|r|r|}
\hline \multirow{2}{*}{ Model } & \multicolumn{2}{|c|}{ Collinearity Statistics } \\
\cline { 3 - 4 } & & Tolerance & \multicolumn{1}{c|}{ VIF } \\
\hline & & & \\
1 & X1 & 0.098 & 10.183 \\
& X2 & 0.989 & 1.011 \\
& X3 & 0.098 & 10.202 \\
\hline
\end{tabular}

\section{Sumber : Hasil Pengolahan Data}

Pada Nilai tolerance variabel Current Ratio, Total Assets Turnover dan Debt to Total Asset berada diatas 0,10 sedangkan nilai VIF variabel Current Ratio, Total Assets Turnover dan Net Profit Margin berada dibawah 10. Dengan demikian hasil uji multikolinearitas tidak terjadi multikolinearitas antar variabel independen.

\section{Tabel Uji Autokorelasi}

\begin{tabular}{|l|c|c|r|r|r|}
\hline Model & $\mathrm{R}$ & $\begin{array}{c}\mathrm{R} \\
\text { Square }\end{array}$ & $\begin{array}{c}\text { Adjusted } \\
\mathrm{R} \\
\text { Square }\end{array}$ & $\begin{array}{c}\text { Std. } \\
\text { Error of } \\
\text { the } \\
\text { Estimate }\end{array}$ & $\begin{array}{l}\text { Durbin- } \\
\text { Watson }\end{array}$ \\
\hline- & $.040^{\mathrm{a}}$ & 0.002 & -0.015 & 3.389 & 2.118 \\
\hline
\end{tabular}

\section{Sumber :Hasil Pengolahan Data}

Menunjukkan bahwa nilai DW yang diperoleh adalah sebesar 2,118 Nilai dl dan du yang diperoleh dengan $\mathrm{K}$ (jumlah variabel sampel)= 3 dan $\mathrm{N}$ (jumlah sampel )=180. Maka dari itu DW akan didapatkan dengan nilai du (batas atas) 1,7091. Kriteria yang terbebas dari autokorelasi positif atau negatif $\mathrm{du}<\mathrm{dw}<4$-dl. Penelitian ini memenuhi kriteria karena $\mathrm{du}$ (batas atas) sebesar $1,7091<2,118<4-1,7224$ maka $(1.7091<2.118<2.277)$ disimpulkan bahwa penelitian ini tidak terjadi autokorelasi 


\section{Uji Heteroskedastisitas}

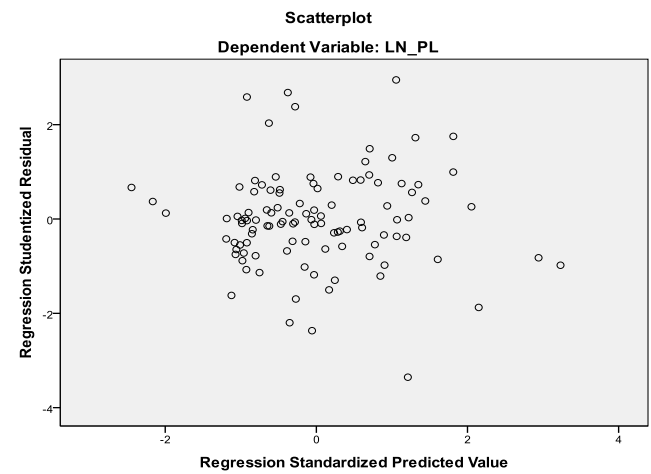

\section{Sumber :Hasil Pengolahan Data}

Pada Gambar IV.5 grafik scatterplot terlihat bahwa titik-titik menyebar secara acak baik diatas maupun dibawah angka nol (0) pada sumbu Y, sebagian berkumpul disatu tempat, sehingga dari grafik scatterplot dapat disimpulkan bahwa tidak terjadi heteroskedastisitas pada model regresi

Pendeteksian ada tidaknya heteroskedastisitas bisa juga dilakukan dengan menggunakan metode Glejser Test, yaitu dengan cara meregresikan nilai absolute residual terhadap variabel independen.

\begin{tabular}{|c|c|c|}
\hline Model & $\mathrm{T}$ & Sig. \\
\hline (Constant) & -1.610 & .110 \\
\hline LN_CR & -1.289 & .200 \\
\hline LN_TATO & -1.186 & .238 \\
\hline LN_NPM & .770 & .443 \\
\hline
\end{tabular}

Uji Glezer

Sumber:Hasil Pengolahan Data

Hasil uji Glejser menunjukan nilai signifikan dari variabel independen Current Ratio sebesar 0,200, Total Assets Turnover sebesar 0,238 ,Net Profit Margin sebesar 0.443 lebih besar dari 0,05 dengan demikian dari hasil Uji Gletser dapat disimpulkan tidak terjadi heteroskedastisitas.

\section{Persamaan Regresi Linier Berganda}

\begin{tabular}{|rl|r|r|}
\hline \multirow{2}{*}{ Model } & \multicolumn{2}{|c|}{$\begin{array}{c}\text { Unstandardized } \\
\text { Coefficients }\end{array}$} \\
\cline { 3 - 4 } & & \multicolumn{1}{|c|}{ B } & Std. Error \\
\hline \multirow{3}{*}{1} & (Constant) & -0.796 & 0.494 \\
& LN_CR & -0.276 & 0.214 \\
& LN_TATO & -0.145 & 0.122 \\
& LN_NPM & 0.106 & 0.138 \\
\hline
\end{tabular}


Sumber: Hasil Pengolahan Data

LN Perubahan Laba $=-0.796-0,276$ LN_CR - 0,145 LN_TATO + 0,106 LN NPM.

\section{Koefisien Determinasi Hipotesis}

\begin{tabular}{|r|r|r|r|r|}
\hline Model & $\mathrm{R}$ & $\begin{array}{c}\mathrm{R} \\
\text { Square }\end{array}$ & $\begin{array}{c}\text { Adjusted } \\
\text { R Square }\end{array}$ & $\begin{array}{c}\text { Std. Error of } \\
\text { the Estimate }\end{array}$ \\
\hline- & $.197^{\mathrm{a}}$ & 0 & 0.011 & 1.5872 \\
\hline
\end{tabular}

\section{Sumber: Hasil Pengolahan Data}

Pada hasil uji koefisisen determinasi diperoleh nilai Adjusted $R$ Square sebesar 0,011. Hal ini menunjukkan 1,1 \% Current Ratio, Total Assets Turn Over,Net Profit Margin dapat menjelaskan hubungan terhadap Perubahan Laba, sedangkan sisanya 98,9 \% dijelaskan oleh variabel lain yaitu diluar penelitian ini contohnya ukuran perusahaan,modal dan deviden.

\section{Pengujian Hipotesis Secara Parsial (t)}

Berdasarkan hasil Uji t dapat dijelaskan sebagai berikut :

\begin{tabular}{|c|c|c|c|c|c|}
\hline \multirow[t]{2}{*}{ Model } & \multicolumn{2}{|c|}{ Unstandardized Coefficients } & $\begin{array}{l}\text { Standardized } \\
\text { Coefficients }\end{array}$ & \multirow[b]{2}{*}{$\mathrm{t}$} & \multirow[b]{2}{*}{ Sig. } \\
\hline & B & Std. Error & Beta & & \\
\hline (Constant) & -.796 & .494 & & -1.610 & .110 \\
\hline LN_CR & -.276 & 214 & -.156 & -1.289 & 200 \\
\hline LN_TATO & -.145 & .122 & -.150 & -1.186 & .238 \\
\hline LN_NPM & .106 & 138 & .109 & .770 & .443 \\
\hline
\end{tabular}

\section{Sumber: Hasil Pengolahan Data}

1. Hasil uji parsial diperoleh nilai thitung Current Ratio sebesar $-1,289<-1,65356$ dengan nilai signifikan 0,200 > 0,05 dengan demikian maka $\mathrm{H}_{0}$ diterima dan $\mathrm{H}_{\mathrm{a}}$ ditolak artinya Current Ratio secara parsial berpengaruh negatif dan tidak signifikan terhadap Perubahan Laba pada perusahaan perdagangan jasa dan investasi periode 2014-2017.

2. Hasil uji parsial nilai -t $t_{\text {hitung }}$ Total Assets Turn Over sebesar $-1,186<-1,65356$ dengan nilai signifikan 0,238>0,05 maka $\mathrm{H}_{\mathrm{o}}$ diterima dan $\mathrm{H}_{\mathrm{a}}$ ditolak artinya Total Assets Turn Over 
R W J Hutagalung, Y N Malau / Jimek vol 3 no 1 tahun 2020

secara parsial berpengaruh negatif dan tidak signifikan terhadap Perubahan Laba pada perusahaan perdagangan jasa dan investasi periode 2014-2017.

3. Hasil uji parsial nilai thitung Net Profit Margin 0,770 $<1,65356$ dengan nilai signifikan 0,443 >0,05 Dengan demikian, nilai $-t_{\text {hitung }}>-t_{\text {tabel }}-0.382>-1,97353$ dan sig 0,908 $>0,05$ maka $\mathrm{H}_{\mathrm{o}}$ ditolak dan $\mathrm{H}_{\mathrm{a}}$ diterima artinya Net Profit Margin berpengaruh positif dan tidak signifikan terhadap Perubahan Laba pada perusahaan perdagangan jasa dan investasi periode 2014-2017

\section{Pengujian Hipotesis secara SimultanUji Simultan (Uji F)}

\begin{tabular}{|rl|r|r|r|r|r|}
\hline \multicolumn{1}{|l|}{ Model } & \multicolumn{1}{|c|}{ Sum of Squares } & \multicolumn{1}{c|}{ Df } & Mean Square & F & \multicolumn{1}{c|}{ Sig. } \\
\hline \multirow{4}{*}{1} & Regression & 10.633 & 3 & 3.544 & 1.407 & $.245^{\mathrm{a}}$ \\
& Residual & 262.01 & 104 & 2.519 & & \\
\cline { 2 - 4 } & Total & 272.64 & 107 & & & \\
\hline
\end{tabular}

\section{Sumber: Hasil Pengolahan Data}

Pada Tabel IV.8 derajat bebas $1\left(\mathrm{df}_{1}\right) \mathrm{k}=3$, dan derajat bebas $2\left(\mathrm{df}_{2}\right)=\mathrm{n}-\mathrm{k}-1=$ 180-3-1 = 176 dimana $\mathrm{n}=$ jumlah sampel, $\mathrm{k}=$ jumlah variabel bebas, nilai $\mathrm{f}$ tabel pada taraf kepercayaan signifikan 0,05 adalah 2,66 dengan demikian $\mathrm{F}$ hitung $=1,407<\mathrm{F}$ tabel = 2,66 dengan tingkat signifikan $0,245>0,05$ maka $\mathrm{H}_{\mathrm{a}}$ diterima dan $\mathrm{H}_{\mathrm{o}}$ ditolak yang artinya secara bersama-sama Current Ratio, Total Assets Turn Over dan Net Profit Margin tidak berpengaruh terhadap Perubahan Laba pada perusahaan perdagangan jasa dan investasi di BEI periode 2014-2017.

\section{HASIL \& PEMBAHASAN}

Berdasarkan pengujian secara parsial menunjukkan bahwa variabel Current Ratio tidak berpengaruh positif dan tidak signifikan terhadap Perubahan Laba pada perusahaan perdagangan jasa dan investasi periode 2014-2017.

Hasil penelitian ini sejalan dengan teori Fahmi (2017) yang menyatakan pentingnya likuiditas dapat dilihat dengan mempertimbangkan dampak yang berasal dari ketidakmampuan perusahaan memenuhi kewajiban jangka pendeknya. Likuiditas dinyatakan dalam perbedaan tingkatan. Kurangnya likuiditas menghalangi perusahaan untuk memperoleh keuntungan dari diskon atau kesempatan mendapatkan keuntungan.

Hasil penelitian ini sejalan dengan hasil penelitian Bonius Omega (2015) yang berjudul Pengaruh Current ratio,Debt to equity ratio dan Net profit margin terhadap perubahan laba terdaftar di BEI tahun 2011-2013. 
Berdasarkan hasil pengujian data menunjukan bahwa Current Ratio tidak berpengaruh positif dan tidak signifikan terhadap Perubahan laba. Hal ini disebabkan bahwa tinggi atau rendahnya nilai current ratio tidak mempengaruhi variasi nilai perubahan laba.

\section{Pengaruh Total Assets Turn Over Terhadap Perubahan Laba}

Berdasarkan pengujian secara parsial menunjukkan bahwa Total Assets Turn Over secara parsial berpengaruh negatif dan tidak signifikan terhadap Perubahan Laba pada perusahaan perdagangan jasa dan investasieriode 2014-2017.

Hasil penelitian ini tidak sejalan dengan teori Menurut Syamsudin ( 2007:62), Total Assets Turn Over menunjukkan tingkat efisiensi penggunaan seluruh aktiva perusahaan didalam menghasilkan volume penjualan tertentu, Semakin tinggi rasio Total Assets Turn Over berarti semakin efisiensi penggunaan keseluruhan aktiva didalam menghasilkan penjualan.

Hasil penelitian ini tidak sejalan dengan hasil penelitian Siti Mas (2016) yang berjudul Pengaruh current ratio, debt to equity ratio, total assets turnover, net profit margin terhadap perubahan laba. Karena tempat waktu penelitian dan tahun yang berbeda.

Berdasarkan hasil pengujian data menunjukan bahwa total assets turnover berpengaruh tidak signifikan terhadap perubahan laba pada perusahaan, hal ini ditenggarahi oleh adanya sebab yaitu perusahaan dalam mengelola total aktiva untuk memperoleh penjualan ada yang tidak efektif sehingga laba yang diterima juga tidak efektif.

\section{Pengaruh Net Profit Margin Terhadap Perubahan Laba}

Berdasarkan pengujian secara parsial menunjukkan bahwa Total Assets Turn Over secara parsial berpengaruh dan tidak signifikan terhadap Perubahan Laba pada perusahaan perdagangan jasa dan investasi periode 2014-2017.

Hasil penelitian ini sejalan dengan teori Menurut Hery (2017: 317), Semakin tinggi marjin laba bersih berarti semakin tinggi pula laba bersih yang dihasilkan dari penjualan bersih. Hal ini dapat disebabkan karena tingginya laba sebelum pajak penghasilan. Sebaliknya, semakin rendah marjin laba bersih berarti semakin rendah pula laba bersih yang dihasilkan dari penjualan bersih. Hal ini dapat disebabkan karena rendahnya laba sebelum pajak penghasilan.

Hasil penelitian ini tidak sejalan dengan hasil penelitian Kiki Suryaningsih (2017) yang berjudul Analisis perngaruh debt to equity ratio (der), net profit margin (npm), gross profit margin (gpm) dan retrun on equity (roe) terhadap perubahan laba pada perusahaan manufaktur sektor industri barang konsumsi yang terdaftar di bursa efek indonesia (bei) periode 2014-2016. Karena tempat waktu penelitian dan tahun yang berbeda. 
Berdasarkan hasil pengujian data menunjukan bahwa Net Profit Margin secara parsial berpengaruh signifikan terhadap perubahan dimana perusahaan mampu mengelola biaya operasionalnya secara efisien serta perusahaan maampu menghasilkan yang optimum dari pengembangan penjualan produknya kepada masyarakat sehingga meningkatkan penjualannya yang berpengaruh dalam pendapatan yang diterima oleh perusahaan.

\section{SIMPULAN \& SARAN}

\section{Kesimpulan}

1. Current Ratio $\left(\mathrm{X}_{1}\right)$ secara parsial berpengaruh negatif dan tidak signifikan terhadap Perubahan Laba (Y) pada perusahaan perdagangan jasa dan investasi yang terdaftar di Bursa Efek Indonesia periode 2014-2017.

2. Total Assets Turnover $\left(\mathrm{X}_{2}\right)$ secara parsial berpengaruh negatif dan tidak signifikan terhadap Perubahan Laba (Y) pada perusahaan perdagangan jasa dan investasi yang terdaftar di Bursa Efek Indonesia periode 2014-2017.

3. Net Profit Margin $\left(\mathrm{X}_{3}\right)$ secara parsial berpengaruh dan tidak signifikan terhadap Perubahan Laba (Y) pada perusahaan perdagangan jasa dan investasi yang terdaftar di Bursa Efek Indonesia periode 2014-2017.

4. Dari hasil pengujian secara simultan, maka dapat dijelaskan bahwa ketiga variabel yaitu Current Ratio $\left(\mathrm{X}_{1}\right)$, Total Assets Turnover $\left(\mathrm{X}_{2}\right)$, dan Net Profit Margin $\left(\mathrm{X}_{3}\right)$ tidak berpengaruh dan tidak signifikan terhadap Perubahan Laba (Y) pada perusahaan perdagangan jasa dan investasi yang terdaftar di Bursa Efek Indonesia periode 2014-2017.

5. Dari hasil pengujian koefisien determinasi diperoleh nilai Adjusted R Square sebesar0,011 Hal ini menunjukkan 1,1\% Current Ratio, Total Assets Turn Over, Net Profit Margin dapat menjelaskan hubungan terhadap Perubahan Laba sedangkan sisanya 98,9\% dijelaskan oleh variabel lain seperti laba perusahaan.

\section{Saran}

Bagi Perusahaan, sebagai sumbangan pemikiran untuk dipakai perusahaan sebagai alat bantu alternatif dalam menilai kembali kinerja keuangan terhadap kemajuan perusahaan di masa mendatang.

1. Bagi Peneliti

Untuk menambah pengetahuan dan memperdalam wawasan yang berhubungan dengan pengaruh current ratio, ukuran perusahaan, net profit margin terhadap struktur modal pada Perusahaan Sektor Industri Barang Konsumsi yang terdaftar di Bursa Efek Indonesia periode 2013-2017. 
2 Bagi Peneliti Selanjutnya

Peneliti ini dapat dijadikan sebagai acuan dan bahan masukan untuk penelitian selanjutnya dengan topik dan variabel yang sama berupa current ratio, ukuran perusahaan, dan net profit margin terhadap struktur modal tetapi dengan objek perusahaan yang berbeda.

3 Bagi Perdagagan jasa dan investasi Disarankan untuk mampu meningkatkan penjualan setiap tahun agar perusahaan bisa mendapatkan laba, karena dengan laba tersebut perusahaan akan mampu bertahan dan tetap beroperasi ke tahun - tahun berikutnya, dan perusahaan dengan lebih mudah untuk mendapatkan pendanaan untuk pengembangan perusahaan.

4 Bagi Universitas Prima Indonesia

Sebagai bahan referensi dan data tambahan untuk melakukan penelitian selanjutnya yang berhubungan dengan bidang akuntansi keuangan dan juga sebagai gambaran tentang sejauh mana kalangan universitas dalam mengerti struktur modal dengan adanya penelitian ini.

\section{DAFTAR PUSTAKA}

Ghozali, Imam,. 2016. Aplikasi Analisis Multivariate dengan Program IBM SPPS.Semarang : Badan Penerbit Universitas Diponegoro.

Harahap, Sofyan Syafri. 2013. Analisis Kritis Atas Laporan Keuangan. Jakarta: Raja Grafindo Persada.

Hery, S. E., M.Si. 2015. Analisis Laporan Keuangan. Yogykarta: CAPS.

Hery, S. E., M.Si. 2017. Analisis Laporan Keuangan. Yogykarta: CAPS.

Kasmir, S.E., M.M. 2012. Pengantar Manajemen Keuangan. Jakarta: Kencana.

Mas, Siti. 2016. Pengaruh Current Ratio, Debt To Equity Ratio, Tottal Assets Turnover, Net Profit Margin, Terhadap Perubahaan Laba Pada Perusahaan. Vol. 5, No.1 Jurnal Sekolah Tinggi Ilmu Ekonomi Indonesia(STEI SIA) Surabaya.

Omega, Bonifasius. 2015. Pengaruh Current Ratio, Debt To Equity Ratio, Net Profit Margin, Terhadap Perubahaan Laba Vol. 2 No. 3 Jurnal Fak. Ekonomi Dan Bisnis, Universitas TELKOM.

Sawir, Agnes S. E., M.Si. 2015. Analisis kinerja keuangan dan perencanaan keuangan perusahaan. Yogykarta: IKAPI 10270

Surya Ningsih, Kiki. 2017. Analisis Pengaruh Debt To Equity Ratio(Der), Net profit Mrgin (NPM), Gross Profit Margin (GPM) dan Return On Equity (ROE) Terhadap Perubahan pada Perusahaan Manufaktur Sektor Industri Barang Konsumsi Yag Terdaftar Di Bursa Efek Indonesia (BE) periode (2014-2016). Vol. 1 No. 12 Jurnal Universitas PGRI Kediri. 